\title{
Evaluation of thermotolerant capacity of lactic acid bacteria isolated from commercial sausages and the effects of their addition on the quality of cooked sausages
}

\author{
Avaliação da capacidade termotolerante de bacterias lácticas isoladas de salsichas comerciais e os efeitos de \\ sua adição na qualidade de salsichas cozidas
}

María de Lourdes PÉREZ-CHABELA ${ }^{1 \star}$, Alfonso TOTOSAUS², Isabel GUERRERO ${ }^{1}$

\begin{abstract}
The thermotolerant capacity of several lactic acid bacteria strains isolated from cooked commercial sausages was determined. Four strains were positively identified as Lactobacillus plantarum, Lactobacillus curvatus, Pediococcus pentosaceus and Pediococcus acidilacti, after surviving thermal treatment $\left(70^{\circ} \mathrm{C}\right.$ during 60 minutes). Thermotolerant strains were inoculated in sausage batters before cooking in order to determine their effect on color, texture, acceptance and inhibition of Enterobacteria during 12 days at $8{ }^{\circ} \mathrm{C}$. No significant effect of the inoculated strains was detected on color parameters. Textural profile parameters, cohesiveness and resilience, were not affected by the inoculation of thermotolerant lactic acid bacteria, but $L$. curvatus sausages resulted softer than the rest of the treatments. Samples inoculated with $L$. curvatus also obtained the lowest scores for the sensory attributes evaluated, with the remaining treatments causing no unfavorable effects on sausage acceptance. There was a reduction in enterobacterial counts after 12 days of cold storage in inoculated samples. The performance of inoculated lactic acid bacteria strains can be explained in a similar way as that of starter cultures in dry-fermented sausages, where the growth in nests impairs other pathogenic microorganisms present in the rest of the sausage, since environmental conditions and the early inoculation of these thermotolerant strains favor them to become the dominant flora.
\end{abstract}

Keywords: lactic acid bacteria; thermotolerance; sausages.

\begin{abstract}
Resumo
A capacidade termotolerante de diversas cepas de bactérias lácticas isoladas de salsichas comerciais cozidas foi determinada. Quatro cepas foram identificadas positivamente como Lactobacillus plantarum, Lactobacillus curvatus, Pediococcus pentosaceus e Pediococcus acidilacti, depois de sobreviver satisfatoriamente ao tratamento térmico $\left(70{ }^{\circ} \mathrm{C}\right.$ durante 60 minutos). As cepas termotolerantes foram inoculadas nas salsichas antes do cozimento, a fim de saber o seu efeito sobre a cor, a textura, a aceitação e a inibição das enterobactérias durante 12 dias a $8{ }^{\circ} \mathrm{C}$. Nenhum efeito significativo foi detectado sobre os parâmetros de cor. Os parâmetros de perfil de textura, coesividade e resiliência, não foram afetados pela inoculação das bactérias lácticas termotolerantes, mas as salsichas inoculadas com L. curvatus apresentaram-se mais macias que as dos outros tratamentos. As amostras inoculadas com L. curvatus também obtiveram as notas mais baixas para os atributos sensoriais avaliados, sendo que os demais tratamentos não provocaram nenhum efeito desfavorável na aceitação das salsichas. Houve uma redução nas contagens das enterobactérias depois de 12 dias de armazenamento a frio nas amostras inoculadas. O desempenho das cepas de bactérias lácticas inoculadas pode ser explicado de uma maneira similar ao das culturas iniciadoras em embutidos fermentados, onde o crescimento em ninhos prejudica outros microorganismos patogênicos no resto da salsicha, pois as condições ambientais e a inoculação precoce destas cepas termotolerantes favorecem-nas a tornarem-se a flora dominante.

Palavras-chave: bactérias lácticas; termotolerância; salsichas.
\end{abstract}

\section{Introduction}

Lactic acid bacteria are Gram positive microorganisms with the main characteristic of producing lactic acid from fermentable carbohydrates. Lactic acid bacteria have an important role in food fermentation provoking changes in odor, flavor and texture, besides their preservative action (HOLZAPFEL; GEINSEN; SCHILLINGER, 1995). This applies to dry fermented meat products, where the inherent stability of these products depends primarily on the natural fermentation ( $\mathrm{pH}$ lowering) to prevent the growth of undesirable microorganisms. Lactic acid bacteria are employed as natural inoculum or added as starter cultures (BACUS, 1984; JAY, 2000). In cooked meat products, thermal treatment performs the most important function by causing destruction of spoilage organisms (PEARSON; GILLETT, 1999). Besides thermal treatment, cooked meat products are generally vacuum packed. Stored under vacuum and refrigeration, the bacterial flora is gradually selected by the environment conditions to anaerobic $\mathrm{CO}_{2}$-tolerant microorganisms, dominated mainly by lactic acid bacteria (VON HOLY; CLOETE; DYKES, 1991). Growth and acid production of lactic acid-forming bacteria are promoted by $\mathrm{pH} \approx 6.0$, water activity of 0.96 due to salt (2.5-3.0\%) and 100 ppm sodium nitrite (MARSHALL.; BAL'A, 2001). Although lactic acid bacteria

Recebido para publicação em 22/9/2006

Aceito para publicação em 17/12/2007 (001861)

Biotechnology Department, Universidad Autónoma Metropolitana Iztapalapa, Av. San Rafael Atlixco, \#86, Mexico City, 09340, Distrito Federal, Mexico,

E-mail:lpch@xanum.uam.mx

${ }^{2}$ Laboratorio de Alimentos, Tecnológico de Estudios Superiores de Ecatepec, Av. Tecnológico y Av. Central, s/n, Ecatepec, 55210, Estado de México, México

${ }^{*}$ A quem a correspondência deve ser enviada 
are considered spoilage flora, the heat treatment employed for sausage processing is adequate from the point of view of microbiological quality and safety, eliminating most microorganisms. Nonetheless, the contribution of lactic acid bacteria to the initial microbial contamination of sausage emulsions is negligible (SACHINDRA et al., 2005).

Isolation and selection of specific lactic acid bacteria strains could be used to improve nutritional and technological properties of meat products. The use of lactic acid bacteria isolated from dry fermented salamis as biopreservative cultures or protective starters has been reported. The isolated strains had the ability to inhibit other spoilage microorganisms or even pathogens, extending the shelf life of the products and increasing meat safety, with no undesirable influence on product quality (METAXOPOULOS; MATARAGAS; DROSINOS, 2003; AMMOR, 2005; PAPAMANOLI et al., 2003). On the other hand, the thermotolerant capacity of some lactic acid bacteria strains isolated from cooked meat products has been reported (VICTORIA-LEÓN et al., 2006; PËTAJA, 1992; MILBOURNE, 1983; FRANZ; HOLY, 1996). These specific strains can be employed as biopreservative cultures that can be inoculated during sausage manufacturing, in order to ensure the dominance of lactic acid bacteria after thermal processing and during cold storage of cured meat products.

In this view, the objective of this study was to evaluate the thermotolerant capacity of lactic acid bacteria isolated from commercial sausages and to verify the effect of their inoculation on the color, texture, sensory acceptance and enterobacterial count of cooked sausages.

\section{Materials and methods}

\subsection{Lactic acid bacteria isolation and biochemical tests}

A total of 12 different commercial brands of Vienna type sausages in closed packages (500 g), collected from supermarkets in Mexico City, were sampled to isolate lactic acid bacteria. Isolation was performed making pertinent dilutions and inoculation on Lactobacilli MRS agar plates (DEMAN; ROGOSA; SHARPE, 1960). A total of 29 strains were identified tentatively as homofermentative lactic acid bacteria, through the following biochemical tests: positive Gram reaction, negative catalase test, negative oxidase test, positive arginine hydrolysis, positive aesculine hydrolysis, growth at 15 and $45^{\circ} \mathrm{C}$, negative gas production (HARRIGAN, 1998) and negative dextrane production (MAYEUX; SANDINE; ELLIKER, 1962). The strains were kept in MRS agar slants at $4{ }^{\circ} \mathrm{C}$ and subcultured every 2 weeks until thermotolerant capacity evaluation.

\subsection{Thermotolerant capacity determination}

Thermotolerant capacity of each of the 29 isolated lactic acid bacteria strains was determined in water baths at different temperatures, adapting the methodology reported by Petäjä (1992) and Anderson et al. (1991). Each strain was subcultured in $10 \mathrm{~mL}$ of MRS broth and incubated at $35^{\circ} \mathrm{C}$ during $24 \pm 2$ hours, until reaching an optical density $(\lambda=650 \mathrm{~nm})$ of approximately one. The tubes were then immersed vertically in a water bath at $70^{\circ} \mathrm{C}$ during 60 minutes. After thermal treatment, surviving microorganisms were counted employing one $\mathrm{mL}$ of the heated tubes in MRS agar plates incubated at $35^{\circ} \mathrm{C}$ during 24 hours, considering as "thermotolerant" the strains with abundant growth ( $>300$ CFU.mL ${ }^{-1}$ ) after thermal treatment. Only thermotolerant strains were further identified and employed for sausage elaboration.

\subsection{Strain identification}

Identification of the thermotolerant strains was carried out employing the API reference method for manual identification (bioMérieux Inc., Hazelwood), using the API-20 Strep for Streptococci and Enterococci and the API-50 CHL Medium for Lactobacillus. Results were analyzed in a Döring-based computer program (DÖRING et al., 1988) to corroborate the possible identification. Four of the strains were positively identified as Lactobacillus curvatus (0.9739), Lactobacillus plantarum (0.9993), Pediococcus acidilacti (0.9735) and Pediococcus pentosaceus (0.9934).

\subsection{Differential scanning calorimetry}

Thermal properties of thermotolerant strains were corroborated by differential scanning calorimetry. Strains were incubated at $35 \pm 2{ }^{\circ} \mathrm{C}$ during 24 hours, until reaching an optical density $(\lambda=650 \mathrm{~nm})$ of approximately one, and diluted at a 1:9 $(\mathrm{v} / \mathrm{v})$ ratio with sterilized water. Aliquots of $20 \mu \mathrm{L}$ were placed in aluminum pans and sealed. Samples were analyzed in a Mettler-Toledo DSC 821 E Differential Scanning Calorimeter (Mettler-Toledo, Griefsen, Switzerland). To reduce the effect due to the MRS broth components, a pan with MRS broth was employed as base line. Temperature was increased from 20 to $200{ }^{\circ} \mathrm{C}$ at a constant rate of $10{ }^{\circ} \mathrm{C} / \mathrm{min}$ (VICTORIA-LEÓN, 2006), calculating the denaturation temperature $\left(\mathrm{T}_{\mathrm{d}}\right)$ and denaturation enthalpy $\left(\Delta \mathrm{H}_{\mathrm{d}}\right)$ for each lactic acid bacteria strain from the respective thermograms.

\subsection{Sausage manufacture}

A Vienna sausage formulation (GUERRERO; PONCE; PÉREZ-CHABELA, 2002) was modified to study the effect of thermotolerant lactic acid bacteria inoculation on final product properties (Table 1). Lean beef and pork were purchased at local abattoirs, removing visible fat and connective tissue. Meat was ground through a $0.42 \mathrm{~cm}$ plate in a Torrey meat grinder

Table 1. Ingredients employed in sausage formulation.

\begin{tabular}{lr}
\hline \multicolumn{1}{c}{ Ingredient } & ${\mathrm{g} \cdot \mathrm{kg}^{-1}}^{-1} .30$ \\
\hline Beef & 152.30 \\
Pork & 355.50 \\
Lard & 122.20 \\
Ice & 264.00 \\
Lactic acid bacteria suspension & 50.00 \\
NaCl & 28.40 \\
Flour & 21.10 \\
Curing salt & 2.50 \\
Hamine ${ }^{\circledR}$ Phosphates & 4.00 \\
\hline
\end{tabular}


M-12-FS (Com. Int. Torrey, Mexico) and mixed with $\mathrm{NaCl}$, curing salt (sodium nitrates, $6.5 \% \mathrm{NaNO}_{3}$ ) and Hammine ${ }^{\varpi} \mathrm{com}-$ mercial phosphate mixture (McCormick PESA, Mexico City), with half of the total ice, during one minute in a 5 qt. Hobart cutter Model 84145 (Hobart Corp., Troy). The rest of the ice and frozen pork back fat were added and batter was mixed until total ingredient incorporation, controlling batter temperature below $12^{\circ} \mathrm{C}$. Previously, a lactic acid bacteria suspension was prepared from each thermotolerant strain incubated in $10 \mathrm{~mL}$ of MRS broth at $35^{\circ} \mathrm{C}$ during 24 hours, until reaching an optical density $(\lambda=650 \mathrm{~nm})$ of approximately one, yielding an inoculum of about $10^{8} \mathrm{CFU} \cdot \mathrm{mL}^{-1}$. The suspension was added to the batter and mixed. A batch with no added lactic acid bacteria was used as control. Batters were stuffed in $20 \mathrm{~mm}$ diameter cellulose casings and cooked in a water bath until reaching an internal temperature of $72^{\circ} \mathrm{C}$, cooled in an ice bath, vacuum packed and stored at $8 \pm 2{ }^{\circ} \mathrm{C}$ until further analysis. Color, texture and acceptance tests were performed after 12 days of storage, average shelf life for cooked sausages before detrimental flavor or microbiological defects appear (SABBAG, 2005; SANTIAGO, 1994).

\subsection{Color determination}

Color of each treatment and control was determined according to the method reported by Totosaus, Alfaro-Rodriguez and Pérez-Chabela (2004), using a Hunter-Lab Colorflex Colorimeter (Hunter Associated Lab, Inc., Reston), against a white standard $(\mathrm{L}=93.2, \mathrm{a}=-1.07, \mathrm{~b}=0.35)$. Readings were taken of the external section of sausages in the port insert rotating each sample $90^{\circ}$ to provide an average color reading per sample. CIE Lab coordinates were reported as luminosity $\left(\mathrm{L}^{\star}\right)$, redness $\left(\mathrm{a}^{\star}\right)$ and yellowness $\left(b^{*}\right)$.

\subsection{Texture profile analysis}

Sausage samples were left to reach equilibrium at room temperature for two hours and cut in $20 \mathrm{~mm}$ height cylinders $(20 \mathrm{~mm} \varnothing)$ and analyzed in a TA-HDi texture analyzer (Texture Technologies, Scarsdale, New York/Stable Micro Systems, Surrey, United Kingdom) equipped with a $25 \mathrm{~kg}$ load cell and a $25 \mathrm{~mm}$ diameter acrylic probe. Samples were axially compressed $50 \%$ of their original height in two consecutive cycles, at a constant cross-head speed rate of $1 \mathrm{~mm} / \mathrm{s}$ with a $5 \mathrm{~s}$ waiting period. Hardness, cohesiveness and resilience were calculated from force-deformation curves (BOURNE, 1978; TEXTURE TECHNOLOGIES, 2003). Results are at least the mean of ten reproducible runs for each treatment.

\subsection{Acceptance test}

In order to determine the effect of the lactic acid bacteria inoculated in the sausages, an acceptance test was performed with a non trained panel. A total of 40 panelists from the university were recruited to evaluate the 5 sausages: 4 elaborated with each one of the different lactic acid bacteria isolated strains and a control (non inoculated) sample. In a previous session, the descriptive attributes that depict the specific sensory characteristics of muscle foods were defined to the panelists (MILLER, 1994): texture, resistance of the sample to the force exerted to be cut or fractured; juiciness, residual humidity perceived in the sample; flavor, characteristic salty flavor perceived in the mouth palate; color, as the characteristic pink color; and overall acceptability, as the sum of the sample attributes. The acceptance test for each sample was carried out in a different session. Sensory attributes were evaluated using a $10 \mathrm{~cm}$ unstructured line scale with "dislike very much" on the left and "like very much" on the right of the line, in order to obtain a numerical response for the perceived intensity of the evaluated attributes, where a score of 10 represents the total acceptance of the product (PEDRERO; PANGBORN, 1996).

\subsection{Enterobacterial count}

Enterobacteria, considered representative spoilage flora in sausages, since they can survive scalding temperatures of 60-62.5 ${ }^{\circ} \mathrm{C}$ (MEAD, 1982), were determined at day 1 and 12 of storage in Eosin-Methylene-Blue (EMB) agar plates (MURTHY, 1984), by standard procedure, reporting the CFU.g-1 of sample.

\subsection{Experimental design and statistical analysis}

The effects of thermotolerant lactic acid bacteria strains on sausage color, texture, acceptance and enterobacterial counts were determined using one-way analysis of variance (DER; EVERITT, 2001) with the PROC ANOVA procedure of the SAS Statistical System v. 8.0 (SAS Institute, Cary, North Carolina). Differential scanning calorimetry results were analyzed by the same procedure. Significant differences among means were determined with the Duncan means test in same statistical program.

\section{Results and discussion}

\subsection{Differential scanning calorimetry}

The four isolated lactic acid bacteria strains presented an abundant survival ( $>300$ CFU.mL ${ }^{-1}$ ) after heating during 30 and 45 minutes at 50, 60 and $70{ }^{\circ} \mathrm{C}$, indicating an inherent thermotolerance capacity. Nonetheless, after heating during 60 minutes at $70{ }^{\circ} \mathrm{C}$, survival of $L$. plantarum and $P$. pentosaceus was lower when compared to L. curvatus and P. acidilacti that presented a more abundant growth. Comparing these results with the DSC analysis, it could be appreciated that the lactic acid bacteria strains showed a similar pattern in the thermograms, with a significant exothermic peak with a temperature onset near $100{ }^{\circ} \mathrm{C}$. No significant difference was detected among the onset temperatures $(p<0.05)$ of the different lactic acid bacteria strains, but there was a significant difference among the denaturation enthalpies $(\mathrm{p}<0.01)$ and the denaturation temperatures $(\mathrm{p}<0.01)$ (Table 2$)$. Conversely to the water bath results, $P$. pentosaceus and L. plantarum presented higher denaturation enthalpies and higher denaturation temperatures than L. curvatus and P. acidilacti. Since the enthalpy of denaturation is an estimate of the thermal energy required to denature the protein and the denaturation temperature is a measure of the thermal stability of the proteins (BOYE; MA; HARWALKAR, 1997), the higher $\Delta H_{d}$ values for the thermotolerant lactic acid bacteria could be explained as their resistance to lose protein 
native conformations, besides the thermal stability of the cell proteins corroborated with the higher $\mathrm{T}_{\mathrm{d}}$ temperatures detected. Large peaks in thermograms of whole cells will either be due to proteins present at high concentrations, or, more probably, to combinations of several protein peaks at the same transition temperature. Besides, differential scanning calorimetry allows whole cells to be studied whilst applying a heat stress and the peaks in the region of the thermogram at which loss of viability was observed are irreversible and most probably due to protein unfolding and denaturation. Contributions from other macromolecules cannot be ruled out; the irreversible component of DNA and RNA melting has been considered to be a minor fraction of total enthalpy (ANDERSON et al., 1991). The main differences between the water bath test and differential scanning calorimetry were the maximum temperature reached and the heating speed. In the water baths, the temperatures were lower but the exposition time was longer (15 to 60 minutes). On the other hand, in the calorimetry trials, the time to reach $100{ }^{\circ} \mathrm{C}$ was approximately 8-10 minutes, similar to the time needed to reach the water bath temperature in the middle of the broth test tube. Water bath thermal treatment allowed the bacteria some kind of adaptation at a maximum temperature of $70^{\circ} \mathrm{C}$. This adaptation would be reflected in the survival in the meat batter conditions after the cooking step. In the same manner, $\Delta \mathrm{H}_{\mathrm{d}}$ values could explain the thermal inactivation of these strains, because the peak in the thermogram was probably due to the contribution of other macromolecules, such as DNA and RNA, besides the contribution of several cell constituent proteins (ANDERSON et al., 1991).

\subsection{Color}

Color in CIE Lab coordinates was affected by the strain employed. The thermotolerant lactic acid bacteria inoculation had no effect on sample luminosity $\left(L^{*}\right)(p>0.05)$, but significantly $(\mathrm{p}<0.05)$ affected the redness $\left(\mathrm{a}^{*}\right)$ and yellowness $\left(\mathrm{b}^{*}\right)$ of the sausages. $P$. pentosaceus resulted in slightly more red samples, and L. plantarum produced relatively lower $\mathrm{a}^{*}$ values. No difference in redness was detected among the rest of the treatments: control, L. curvatus or P. acidilacti. Yellowness of the samples was relatively higher when $L$. plantarum was inoculated in sausages, whereas L. curvatus reduced the value of this parameter, when compared to the control (Table 3). In cured meat products, discoloration could be caused by lactic acid bacteria that produce catalase and peroxide, oxidative agents, which degrade meat pigments (PÉREZ-DUBE; ANDÚJAR-ROBLES, 2000). However, although the lactic acid bacteria employed

Table 2. Denaturation enthalpy and temperatures for the thermotolerant lactic acid bacteria.

\begin{tabular}{lccc}
\hline & $\begin{array}{c}\text { Denaturation } \\
\text { enthalpy } \Delta \mathrm{H}_{\mathrm{d}}\left(\mathrm{kJ} . \mathrm{g}^{-1}\right)\end{array}$ & \multicolumn{2}{c}{ Denaturation temperature $\mathrm{T}_{\mathrm{d}}\left({ }^{\circ} \mathrm{C}\right)$} \\
\cline { 2 - 4 } L. curvatus & $0.627^{\mathrm{c}}$ & $100.50^{\mathrm{a}}$ & $113.78^{\mathrm{bc}}$ \\
L. plantarum & $0.977^{\mathrm{ab}}$ & $100.26^{\mathrm{a}}$ & $114.95^{\mathrm{a}}$ \\
P. acidilacti & $0.773^{\mathrm{bc}}$ & $100.58^{\mathrm{a}}$ & $113.42^{\mathrm{c}}$ \\
P. pentosaceus & $1.158^{\mathrm{a}}$ & $99.14^{\mathrm{a}}$ & $114.09^{\mathrm{b}}$ \\
\hline
\end{tabular}

$a, b$ Means with the same letter in the same column are not significantly different $(\mathrm{p}>0.05)$. were catalase and peroxide negative, minor changes detected in sausage surfaces could be due to changes in metabolism, since it has been demonstrated for some lactic acid bacteria that the production of acetate may be induced during conditions simulating semistarvation (BORCH; BERG; HOLST, 1991).

\subsection{Texture profile analysis}

The inoculation of thermotolerant lactic acid bacteria had slight effects on sausage texture. Only hardness was significantly affected $(\mathrm{p}<0.05)$ by the kind of lactic acid bacteria strain inoculated. L. curvatus samples resulted in lower hardness values, and no major difference was detected between the control and the rest of the treatments. No significant difference $(p>0.05)$ was detected in cohesiveness and resilience (Table 4). Differences in sausage hardness could be due to a relatively higher quantity of lactic acid produced by L. curvatus. Lower $\mathrm{pH}$ in cooked salami-type sausages resulted in more disruption of protein coagulates formed during heating, producing a less dense structure, reflected in lower hardness values (BARBUT, 2006). The dominating lactic acid bacteria are known to produce acids, such as lactic, acetic and formic acids, the level of which, depending on genus, species and growth conditions, cause a decrease in pH (BORCH; BERG; HOLST, 1991). Working with the same strains, Reyes-Menendez (2005) reported that L. curvatus presented a higher lactic acid production and a concomitant lower $\mathrm{pH}$ when the lactic acid bacteria were grown in raw meat. Despite the relatively higher acidity in the sausage matrix, the integrity of the samples, related to cohesiveness and resilience, were not affected, since the electrophoretic patterns from cooked batter protein extracts presented no proteolytic activity caused by the inoculated strains. Nonetheless, proteolytic activity of lactic acid bacteria (L. hoimohiochii and L. curvatus) in dry fermented sausages has been reported (PEREIRA; BARRETO CRESPO; ROMÃ̃, 2001).

Table 3. Instrumental color results for the sausages inoculated with thermotolerant lactic acid bacteria.

\begin{tabular}{lccc}
\hline & Luminosity $\left(\mathrm{L}^{*}\right)$ & Redness $\left(\mathrm{a}^{\star}\right)$ & Yellowness $\left(\mathrm{b}^{*}\right)$ \\
\hline Control & $68.35 \pm 9.63^{\mathrm{a}}$ & $9.09 \pm 1.28^{\mathrm{ab}}$ & $12.55 \pm 1.76^{\mathrm{ab}}$ \\
L. curvatus & $69.48 \pm 9.79^{\mathrm{a}}$ & $9.39 \pm 1.32^{\mathrm{ab}}$ & $11.63 \pm 1.63^{\mathrm{b}}$ \\
L. plantarum & $71.39 \pm 10.0^{\mathrm{a}}$ & $8.45 \pm 1.19^{\mathrm{b}}$ & $13.26 \pm 1.86^{\mathrm{a}}$ \\
P. acidilacti & $68.38 \pm 9.63^{\mathrm{a}}$ & $9.34 \pm 1.31^{\mathrm{ab}}$ & $12.38 \pm 1.86^{\mathrm{ab}}$ \\
P. pentosaceus & $65.37 \pm 9.21^{\mathrm{a}}$ & $10.08 \pm 1.42^{\mathrm{a}}$ & $12.62 \pm 1.77^{\mathrm{ab}}$ \\
\hline
\end{tabular}

a,b Means with the same letter in the same column are not significantly different $(\mathrm{p}>0.05)$.

Table 4. Texture profile analysis results for the sausages inoculated with thermotolerant lactic acid bacteria.

\begin{tabular}{lccc}
\hline & Hardness $(\mathrm{N})$ & Cohesiveness & Resilience \\
\hline Control & $23.62 \pm 3.33^{\mathrm{a}}$ & $0.986 \pm 0.14^{\mathrm{a}}$ & $0.697 \pm 0.09^{\mathrm{a}}$ \\
L. curvatus & $19.39 \pm 2.73^{\mathrm{c}}$ & $0.996 \pm 0.14^{\mathrm{a}}$ & $0.707 \pm 0.10^{\mathrm{a}}$ \\
L. plantarum & $22.71 \pm 3.20^{\mathrm{ab}}$ & $0.985 \pm 0.13^{\mathrm{a}}$ & $0.725 \pm 0.10^{\mathrm{a}}$ \\
P. acidilacti & $25.03 \pm 3.52^{\mathrm{a}}$ & $0.969 \pm 0.14^{\mathrm{a}}$ & $0.726 \pm 0.10^{\mathrm{a}}$ \\
P. pentosaceus & $20.92 \pm 2.91^{\mathrm{bc}}$ & $0.992 \pm 0.13^{\mathrm{a}}$ & $0.741 \pm 0.10^{\mathrm{a}}$ \\
\hline
\end{tabular}

${ }_{a, b}$ Means with the same letter in the same column are not significantly different $(\mathrm{p}>0.05)$. 


\subsection{Acceptance test}

The inoculation of thermotolerant lactic acid bacteria strains significantly affected $(\mathrm{p}<0.01)$ the acceptance of cooked sausages. In general, samples inoculated with $L$. curvatus obtained the lowest scores (close to 5, line midpoint) for all the attributes evaluated. The rest of the treatments obtained scores close to or even higher than the control sample, with no unfavorable effects on sausage acceptance (Table 5). The higher lactic acid production of $L$. curvatus probably explains the lower acceptance of this sample. Working with different strains of thermotolerant lactic acid bacteria, Victoria-León et al. (2006) reported that, after 12 days of cold storage, sausages inoculated with $L$. lactis (ATCC 1154) and L. piscicola (MXVK76) had improved flavor and overall acceptance when cooked, whereas Enterococcus sp. (MXVK29) and L. alimentarius (ATCC 29643) obtained the lowest scores when compared to a non inoculated control. In general, lactic acid bacteria improved the sensory attributes of cooked sausages (MILANI, 2003), but with a slightly acid taste (GARRIGA; JULIÁ; HUGAS, 1998).

\subsection{Enterobacterial count}

Enterobacterial counts were lower for the inoculated samples than for the control after 12 days of storage. In general, there was a reduction in enterobacterial counts after 12 days of cold storage. The major antagonistic effect of lactic acid bacteria on Enterobacteria was for L. curvatus (Table 6). Due to the facultative anaerobic nature of most Enterobacteria, they tend to predominate in vacuum-packaged products, but this group competes poorly with lactic acid bacteria under cold storage conditions (VON HOLY; CLOETE; DYKES, 1991). The application of lactic acid bacteria as a starter culture caused a reduction in S. aureus and other Enterobacteria in relation to non inoculated meat products (MILANI et al., 2003; BALDUINO et al., 1999).

Although the heat treatment employed for sausage processing was adequate from the point of view of microbiological quality and safety, the presence of a small number of Enterobacteria in the cooked sausages can be attributed to contamination after cooking, since storage and packaging conditions did not favor the growth of these Enterobacteria. Besides, lactic acid bacteria present a much lower contribution to the initial microbial contamination of sausage emulsions (PAPAMANOLI et al., 2003). Lactic acid bacteria, as added cultures or native flora, predominated over the enterobacterial population in cooked sausages stored at $4{ }^{\circ} \mathrm{C}$ during 12 days (VICTORIA-LEÓN et al., 2006). However, although lactic acid bacteria are the dominant flora in vacuum-packed sausages, the presence of these strains seems not to negatively affect the shelf life of the products (KORKEALA et al., 1989), since the final population of the spoilage microorganisms, namely lactic acid bacteria, cannot be the only parameter or indicator for the evaluation of the shelf life of the meat products, but the final population of Pseudomonads and Enterobacteria was not high (MARSHALL; BAL'A, 2001).

These beneficial effects due to the application of the thermotolerant lactic acid bacteria inoculated in cooked sausages can be explained in an analogous way to the use of lactic starters in dry fermented meat products. In dry fermented sausages, the added starter cultures, as well as the natural flora, are not evenly distributed but are immobilized in cavities in the sausage mix. Then, during the ripening process, the properties of the sausages change in the desired direction (nitrate reduction, lactic acid production, catalase activity, etc.) because 'large areas' of the sausage matrix which are located between these cavities (separated by 100 to $5000 \mu \mathrm{m}$ ) must be influenced by the bacteria growing nest (LEISTNER, 1990). For cooked emulsified sausages, a similar pattern could be expected, since, if it is assumed that the microorganisms which grow in such nests are in competition, and then the individual bacteria will compete for nutrients and impair each other with metabolic products, such as lactic acid. Inhibitory substances or bacteriocins which produced in 'Lactobacilli nests' will diffuse and thus inactivate other pathogenic microorganisms present in other nests. Moreover, the heterogeneous composition of emulsified meat products, such as sausages, allowed the growth of thermotolerant lactic acid bacteria, serving as a protective media when the strains are in the core, allowing the adaptation of thermotolerant strains by successive thermal shocks applied during cooking, since surface isolated bacteria were not very heat resistant, because they are probably due to contamination after cooking (PËTAJA, 1992; MILBOURNE, 1983; PËTAJA, 1991).

Table 6. Enterobacterial counts (CFU.g ${ }^{-1}$ sample) for the sausages inoculated with thermotolerant lactic acid bacteria.

\begin{tabular}{lcc}
\hline & Day 1 & Day 12 \\
\hline Control & $3.57 \pm 0.50^{\mathrm{a}}$ & $4.30 \pm 0.60^{\mathrm{ab}}$ \\
L. curvatus & $4.67 \pm 0.66^{\mathrm{a}}$ & $2.55 \pm 0.36^{\mathrm{d}}$ \\
L. plantarum & $3.40 \pm 0.48^{\mathrm{b}}$ & $3.50 \pm 0.49^{\mathrm{b}}$ \\
P. acidilacti & $4.13 \pm 0.58^{\mathrm{a}}$ & $3.25 \pm 0.45^{\mathrm{b}}$ \\
P. pentosaceus & $4.30 \pm 0.61^{\mathrm{a}}$ & $3.05 \pm 0.43^{\mathrm{c}}$ \\
\hline
\end{tabular}

a,b Means with the same letter in the same column are not significantly different ( $\mathrm{p}>0.05)$.

Table 5. Acceptance test with a non trained panel of the sausages inoculated with thermotolerant lactic acid bacteria.

\begin{tabular}{lccccc}
\hline & Texture & Juiciness & Flavor & Color & Overall acceptability \\
\hline Control & $6.50 \pm 0.91^{\mathrm{b}}$ & $7.53 \pm 1.06^{\mathrm{a}}$ & $6.39 \pm 2.20^{\mathrm{ab}}$ & $6.27 \pm 0.88^{\mathrm{c}}$ & $6.47 \pm 0.92^{\mathrm{b}}$ \\
L. curvatus & $5.75 \pm 0.81^{\mathrm{c}}$ & $5.95 \pm 0.83^{\mathrm{b}}$ & $5.05 \pm 2.47^{\mathrm{c}}$ & $3.97 \pm 0.55^{\mathrm{d}}$ & $4.40 \pm 0.62^{\mathrm{d}}$ \\
L. plantarum & $6.98 \pm 0.98^{\mathrm{ab}}$ & $8.25 \pm 1.16^{\mathrm{a}}$ & $7.00 \pm 2.51^{\mathrm{a}}$ & $7.86 \pm 1.10^{\mathrm{b}}$ & $8.31 \pm 1.17^{\mathrm{a}}$ \\
P. acidilacti & $6.25 \pm 0.88^{\mathrm{bc}}$ & $7.49 \pm 1.05^{\mathrm{a}}$ & $6.36 \pm 2.33^{\mathrm{ab}}$ & $5.85 \pm 0.82^{\mathrm{c}}$ & $5.69 \pm 0.80^{\mathrm{c}}$ \\
P. pentosaceus & $7.43 \pm 1.04^{\mathrm{a}}$ & $8.03 \pm 1.13^{\mathrm{a}}$ & $6.81 \pm 2.06^{\mathrm{a}}$ & $8.07 \pm 1.41^{\mathrm{a}}$ & $6.77 \pm 0.95^{\mathrm{b}}$ \\
\hline
\end{tabular}

a,b Means with the same letter in the same column are not significantly different $(p>0.05)$. 


\section{Conclusion}

Isolation and identification of natural lactic acid bacteria strains from cooked sausages with thermotolerant capacity was achieved. The different thermal treatments, i.e., culture broth at different temperatures and times in water baths and the DSC thermograms, showed an inherent heat resistance capacity of these strains even at thermal process temperatures. The strains inoculated in the sausages produced no major or significant changes in color, texture and acceptance, probably due to their homofermentative metabolism, during the storage time, becoming the dominant flora during this period because of their inoculation at the sausage batter manufacturing. In this view, thermotolerant lactic acid bacteria could be employed as bioprotective cultures to improve microbial safety in cooked meat products, since the enterobacterial counts were diminished during storage.

\section{References}

AMMOR, S. et al. Characterization and selection of Lactobacillus sakei strains isolated from traditional dry sausage for their potential use as starter culture. Food Microbiol., v. 22, n. 6, p. 529-538, 2005.

ANDERSON, W. et al. Thermal inactivation of Listeria monocytogenes studied by differential scanning calorimetry. J. General Microbiol., v. 137, p. 1419-1424, 1991.

BACUS, J. Utilization of Microorganisms in Meat Processing. New York: John Wiley \& Sons, 1984.

BALDUINO, R. et al. Cultura lática mista com potencial de aplicação como cultura iniciadora em produtos cárneos. Ciênc. Tecnol. Aliment., v. 19, n. 3, p. 356-362, 1999.

BARBUT, S. Fermentation and chemical acidification of salami-type products - Effect on yield, texture and microstructure. J. Muscle Foods, v. 17, n. 1, p. 34-42, 2006.

BORCH, E.; BERG, H.; HOLST, O. Heterolactic fermentation by a homofermentative Lactobacillus sp. during glucose limitation in anaerobic continuous culture with complete cell recycle. J. Appl. Bacterol., v. 71, p. 265-269, 1991.

BOURNE, M. C. Texture profile analysis. Food Technol., v. 32, n. 7 , p.62-66, 72, 1978.

BOYE, J. I.; MA, C. Y.; HARWALKAR, V. R. Thermal denaturation and coagulation of proteins. In: DAMODARAN, S. PARAF. A. (Ed.) Food Proteins and Applications. New York: Marcel Dekker, p. 25-56, 1997.

DEMAN, J. C.; ROGOSA, M., SHARPE, M. E. A medium for the cultivation of lactobacilli. J. Appl. Bacteriol., v. 23, p. 130-135, 1960.

DER, G.; EVERITT, B. S. Handbook of Statistical Analyses Using SAS, $2^{\text {nd }}$ edition. Boca Raton: Chapman and Hall/CRC, p. 101-130, 2001.

DÖRING, B. et al. Computer-assisted identification of lactic acid bacteria from meats. System. Appl. Microbiol., v. 11, p. 67-74, 1988.

FRANZ, A.; HOLY, A. Thermotolerance of meat spoilage lactic acid bacteria and their inactivation in vacuum packaged Vienna sausages. Int. J. Food Microbiol., v. 29, n. 1, p. 59-73, 1996.

GARRIGA, M.; JULIÁ, A.; HUGAS, M. Experiencias piloto para el control de patógenos en embutidos poco acidificados mediante la utilización de cultivos bioprotectores. Eurocarne, v. 69, p. 61-66, 1998.
GUERRERO, I.; PONCE, E.; PÉREZ-CHABELA, M. L. Curso Práctico de Tecnología de Carnes y Pescados. México City: Universidad Autónoma Metropolitana Press, p. 71-82, 2002.

HARRIGAN, W. F. Laboratory Methods in Food Microbiology, 3rd. edition. San Diego: Academic Press, San Diego, p. 100-129, 1998.

HOLZAPFEL, W. H.; GEINSEN, R.; SCHILLINGER, U. Biological preservation of foods with reference to protective cultures, bacteriocins and food grade enzymes. Int. J. Food Microbiol., v. 24, n. 3, p. 343-362, 1995.

JAY, J. M. Modern Food Microbiology, 6th ed. Gaithersburg: Aspen Publication, p. 87-99, 2000.

KORKEALA, H. et al. Shelf-life of vacuum-packed cooked ring sausages at different chill temperatures. Int. J. Food Microbiol., v. 9, n. 3, p. 237-247, 1989.

LEISTNER, L. Fermented and intermediate moisture products. In: Proceedings of 36th International Congress of Meat Science and Technology. 1990, La Havana, Cuba, p. 842-855.

MARSHALL, D. L.; BAL'A, M. F. A. Microbiology of Meats. In: HUI, Y. H. et al. (Ed.). Meat Science and Applications. New York: Marcel Dekker, p. 159-163, 2001.

MAYEUX, J. V.; SANDINE, W. W. E.; ELLIKER, P. R. A selective medium for detecting Leuconostoc organisms in mixed strain starter cultures. J. Dairy Sci., v. 45, p. 655-656, 1962.

MEAD, G. C. Microbiology of poultry and game bird. In: BROWN, M. H. (Ed.) Meat Microbiology. Essex: Applied Science, p. 76-87, 1982.

METAXOPOUlOS, J.; MATARAGAS, M.; DROSINOS, E. H. Microbial interaction in cooked cured meat products under vacuum or modified atmosphere at $4{ }^{\circ} \mathrm{C}$. J. Appl. Microbiol., v. 93, n. 3, p. 363-373, 2003.

MILANI, L. I. G. et al. Bioproteção de lingüiça de frango. Ciênc. Tecnol. Aliment., v. 23, n. 2, p. 161-166, 2003.

MILBOURNE, K. Thermal tolerance of Lactobacillus viridescens in ham. Meat Sci., v. 9, n. 2, p. 113-119, 1983.

MILLER, R. K. Sensory methods to evaluate muscle foods. In: KINSMAN, D. M.; KOTULA, A. W.; BREIDENSTEIN, B.C. (Ed.). Muscle Foods, Meat, Poultry and Seafood Technology. New York: Chapman \& Hall, p. 333-360, 1994.

MURTHY, T. Relative numbers of coliforms, enterobacteriaceae and total aerobic bacteria counts as determined from minced goat meat. J. Food Protect., v. 47, p. 142-144, 1984.

PAPAMANOLI, E. et al. Characterization of lactic acid bacteria isolated from a Greek dry-fermented sausage in respect to their technological and probiotic properties, Meat Sci., v. 65, n. 2, p. 859-867, 2003.

PEARSON, A. M.; GILleTt, T. A. Processed Meats, $3^{\text {rd }}$ edition. Gaithersburg: Aspen Publication, 1999.

PEDRERO, D.; PANGBORN, R. Evaluación Sensorial de los Alimentos. Métodos Analíticos. México City: Editorial Alhambra Mexicana, p. 67-102, 1996.

PEREIRA, C. I.; BARRETO CRESPO, M. T.; ROMÃO, M. V. Evidence for proteolytic activity and biogenic amines production in Lactobacilus curvatus and L. homohiochii. Int. J. Food Microbiol., v. 68, n. 3, p. 211-216, 2001.

PÉREZ-DUBE, D.; ANDÚJAR-ROBLES, G. Cambios de coloración de los productos cárnicos. Rev. Cubana Aliment. Nutr., v. 14, n. 2 , p. 114-123, 2000.

PËTAJA, E. Heat resistance of two streptococci isolated from the core of cooked meat products made from coarsely ground pork. 
In: Proceeding of the 38th International Conference of Meat Science and Technology Proceedings. 1992, Clermont-Ferrand, France, p. 723-725.

. Meat products made of coarsely ground pork: survival of lactic acid bacteria and pseudomonads after heat treatment. In: Proceeding of the 37th International Congress of Meat Science and Technology. 1991, Kulmbach, Germany, p. 605-608.

REYES MENENDEZ, C. V. Efecto de Bacterias Lácticas Termorresistentes sobre el Color y la Textura de Batidos Cárnicos Bajos en Grasa y Sal. Ciudad de México, 2005, 72 p., Tesis (Maestro en Biotecnología), Universidad Autónoma Metropolitana.

SABBAG, N. G. et al. Quality evaluation of commercial frankfurter by deterioration index method. J. Food Quality, v. 28, n. 5-6, p. 467-478, 2005.

SACHINDRA, N. N. et al. Microbial profile of buffalo sausage during processing and storage. Food Control, v. 16, n. 1, p. 31-35, 2005.
SANTIAGO, L. G. et al. Kinetics of physicochemical and microbiological changes during storage of commercial frankfurters. Food Sci. Tech. Int., v. 10, n. 2, p. 109-116, 1994.

TEXTURE TECHNOLOGIES. Textural profile analysis explained \& annotated. Available at: <http: //www.texturetechnologies.com/ texture_profile_analysis.html>. Access on: 15 Nov, 2003.

TOTOSAUS, A.; ALFARO-RODRÍGUEZ, R. H.; PÉREZ-CHABELA, M. L. Fat and sodium chloride reduction in sausages using $\kappa$-carrageenan and other salts. Int. J. Food Sci. Nutrit., v. 55, n. 5, p. 371-380, 2004.

VICTORIA-LEÓN, T. et al. Efecto de bacterias ácido lácticas termoresistentes en salchichas cocidas. Cienc. Tecnol. Aliment., v. 5, n. 2, p. 135-141, 2006.

VON HOLY, A.; CLOETE, T. A.; DYKES, G. A. Quantification and characterization of microbial populations associated with spoil, vacuum packed Vienna sausages. Food Microbiol., v. 8, n. 2, p. 95-104, 1991. 